\title{
Examining the Relationship between the Clothing and Textiles Curriculum and the World of work
}

\author{
Verity Muzenda \\ School of Further and Continuing Education, University of Fort Hare, South Africa \\ Email: muzendaverity@yahoo.co.za \\ Ntombozuko Duku \\ School of General and Continuing Education, University of Fort Hare, South Africa
}

\section{Doi:10.5901/mjss.2014.v5n16p409}

\begin{abstract}
The delivery of the Clothing and Textiles curriculum has been marred by a myriad of challenges, and this has not spared universities. The relationship between universities and the world of work has been the most contested issues in Technical Vocational Education. The sample was made up of 60 respondents. Interviews, questionnaires, focus group discussions, document analysis and observations were employed as data collecting instruments. Quantitative data was analysed using the SPSS Statistical package and qualitative data was analysed thematically. The mixed method design which is rooted in the post-positivist research paradigm that integrates concurrent procedures in the collection, analysis and interpretation of the data was used. The study established that there was no collaboration between universities and industries. The study concluded that the lack of a clear link between universities and industries was a major contributory factor to the type of students universities were producing; students who lack the qualities needed by the world of work. The researchers recommended that there should be collaboration among University management, lecturers and the industry during curriculum design and monitoring to improve their attachment and sense of ownership of these programmes. Time for attachment should be lengthened so that students leave the industry well equipped with relevant skills and knowledge. There is need for the universities in liaison with industries to come up with policies that focus on student attachment.
\end{abstract}

Keywords: Clothing and Textiles, Technical Vocational Education, World of work, attachment

\section{Introduction}

The development of skills for employment is an important international policy area, but one that has been relatively ignored in sub-Saharan Africa (UNESCO, 2010). In particular, concerns about the effectiveness and feasibility of skills transfer between higher education and the world of work, suggest that care must be exercised, especially when skills linked to employability are implanted within or added to existing programmes of study in universities (King, 2011). There is a significant problem of graduate unemployment and of graduates progressing to low skilled work in the non-formal sector in Zimbabwe. In many African countries, the second-class status of Technical Vocational Education (TVE) makes young people hesitant to choose TVE as their career preparation (UNESCO, 2003).

The link between universities and the world of work is weak or non-existent in many developing countries (Werfhorst, 2007). Baba, Shichijo and Sedita (2009), Bekkers and Freitas (2008), posit that, the link between universities and industries should yield a significant transformation in as far as TVE is concerned. As a result, there is need for a professional to continually learn throughout their career, with the intention of deepening their knowledge, skills, and staying abreast of developmental issues (Bekkers \& Freitas, 2008). The skills and education system form a fundamental pillar for the success of an industrial policy. There is currently insufficient integration between industrial policy objectives and skills in the education system. There is therefore a need from much closer alignment between industrial policy and skills and education development, particularly with respect to sector strategies (DTI, 2009). The labour market is unable to absorb the existing university graduates while, paradoxically, there are not enough skills in the general labour force to stimulate the creation of firms in the technology fields to generate more jobs in these areas (Bekkers \& Freitas, 2008).

Makochekanwa and Kwaramba (2010) lamented that the training received by Clothing and Textiles (CT) students was not equipping them enough to face the world ahead of them. The contact time does not include attachment to industries but only theoretical aspects of their modules. If it does include the contact time, it will not give the students 
enough time to acquire all the relevant skills necessary for them to fit in the world of work. The practicals students do in laboratories are not relevant enough to equip them with the necessary skills. Kariwo (2007), state that universities play a crucial role in the economic development of a country. The same author further elaborates that in developing countries, universities are the only institutions which can produce manpower with the skills required by the world of work. Universities play a crucial role in society as producers and transmitters of knowledge. However, as a result of globalisation, such institutions are in a state of decline and this brings the situation to the attention of the International community (Kariwo, 2007), hence the researcher's interest in this area.

According to Turnball, Littlejohn and Allan (2012) there is need for universities to equip students with skills that are relevant to the world of work. The same authors further maintain that there should be collaborative learning strategies between universities and the world of work in this era when there is an outcry for the need of to prepare students for the workplace. Harasim (2000) comments that nowadays there is a privilege which can allow universities to involve the world of work in coming up with the curriculum. Turnball, Littlejohn and Allan (2012) maintain that in designing educational outcomes, collaboration, sharing of knowledge and ideas between lecturers, students and the workplace is greatly valued. The same authors further comment that there is need for all parties involved to cooperate with each other, and commit to the collaborative achievement of their intended goals, that is designing a curriculum which is in line with the world of work. Furthermore, Turnbull, Littlejohn and Allan (2012) elaborate that collaborative learning strategies between Institutions of Higher Learning $(\mathrm{IHL})$ and the world of work is growing at an alarming rate as lecturers seek improved ways to prepare students for the workplace. A curriculum designed as a result of this collaboration is likely to produce desirable results since the integration of views between the two parties involved will result in the production of wholesome students with qualities that satisfy the needs of both the universities and industries.

Ball (2002: 11) affirms:

Higher education will need to understand the nature of creative enterprises to help students and graduates to learn about the industry and how to access training and development opportunities. The implications are that staff needs to update their knowledge about the world of work, take more responsibility for preparing students for the transition to work and encourage multidisciplinary working to mirror what is happening in the workplace. This involves a shift towards an outward-looking culture providing a bridge with the real world, extending beyond the formal undergraduate curriculum.

According to Royal College of Art (1998) studies have shown that students who graduate from universities find it difficult to make a smooth change over from the universities to the world of work due to lack of skills and this hinders their progress. Furthermore, the same source further alludes that the students feel inadequately prepared to face the realities in the workplace and the students would have liked their course content to have been more inclined to the needs of the word of work. A study of Royal College of Art instituted that students feel discouraged the period immediately after entering the world of work due to lack of confidence, support and the increasing demands of paying for accommodation , transport and debts (Royal College of Art, 1998). It is worth noting that similar results were produced by the study that was done into graduate design and craft businesses at the University of Brighton (Ball \& Price, 1999). In this study, expertise and confidence in the workplace were crucial in one's transition from the universities into the world of work, yet these attributes were often found to be lacking in most students entering the world of work. Some of the students were quote to have said "If only someone would point me in the right direction I need someone to tell me what to do next" (Ball \& Price, 1999: 27). Burroughs (2000); Ball (1999) established this to be a major concern since one can be taught to be an expert in an area, but it was difficult to teach confidence for it is an attribute developed in students as they learn through organised active learning, practical oriented projects, and collaboration between universities and industries.

China is an example of a country that reoriented its TVE system to enhance its link with the industry (Yorke \& Longden, 2004). After the Cultural Revolution, China realised that the old political and ideological functions of the universities had not brought about modernisation. A new emphasis on higher education and science and technology as the key to development emerged. As a result, the Chinese government launched a concerted effort to enhance the capacity of universities to carry out research linked to economic development needs of the country (World Bank, 2002). According to Yorke and Longden (2004), the leading national universities began to develop two types of staff: teaching faculty that spent 70 percent of their time teaching and 30 percent carrying out research, and research faculty who spent 70 percent of their time on research and 30 percent on teaching. As a result, university cooperation with industry and the National Academy of Sciences increased.

Another barrier to the link between universities and the world of work is the selection criteria used for students to take up CT (Castells, 2006). Literature has revealed that selection of students in most countries is done through assessment of aptitudes and competencies as well as through examinations (Werfhorst, 2007). The performance of 
students in the in the world of work is determined by the calibre of students selected into the CT programme. According to Werfhorst, (2007), the choice of access policies has implications for quality and efficiency. Thus inappropriate selection policies produce repetition, dropouts, and waste in IHL. To promote quality and the best use of resources, admissions policies must be fair and be based on candidates' merits and ability to benefit from higher education and not otherwise (Castells, 2006). Access policies must also encourage institutions to respond to the demand for different types of TVE by different stakeholders, and to recognise and react to labour market signals. It is worth noting however, that to cope with excess demand and to ensure that graduates' skills are relevant to the labour market's needs, access policies should reflect the diversity in students' backgrounds and abilities. They should encourage institutions to adjust their objectives and programs to respond to this diversity, and to allocate students among fields of study and institutions according to ability and area of TVE desired. For this study, the link between industries and universities is one area to explore since it is part of the concerns raised by different stakeholders.

In many developing countries admissions tests may not be valid in predicting applicants' ability to benefit from CT in universities. Often a lack of staff qualified in assessment techniques and practices hampers the development of reliable measures of achievement and learning ability. It has been instituted that assessment can have immense implications and can cripple a student permanently if it is not authentic (Maree \& Frazer, 2008). For example, the selection instrument in Cameroon does not correlate with educational or labour market outcomes. Rather, it is a convenient tool given limited resources and places, and the need to give all taxpayers' children a fair chance to enter publicly-funded institutions. Similarly, in Uganda the demand for TVE in universities continues to expand despite no assurance of employment and the lack of relevance of the studies offered to the world of work. On the other hand, China uses its university selection examination to guarantee the quality of education and to make the best use of its resources. In the 1970s Chinese authorities replaced national examinations based on academic criteria with family background and political criteria. This policy crippled China's universities and slowed its economic growth for a decade. China reinstated the rigorous national academic examinations in the 1980s as part of its modernization effort. The current policy is to achieve a certain level of development through high quality TVE, and to address equity problems gradually.

In Malaysia a small TVE sector has been equated with quality. TVE spaces were restricted and selection policies were supposed to select the top performers to ensure that all students graduated with appropriate skills. However, it should be noted that selection and recruitment policies will determine the quality of graduates produced; the level of knowledge and skills they attain; and their adaptability, creativity, and entrepreneurial skills. Such issues are an important dimension of the policy and institutional setting of TVE, and will influence the pace and success of change and development in the world of work in many countries. On the contrary, it should also be noted that failure as signalled by assessments can reduce self-esteem, lead to inhibited social relations associated with shame, can take the enjoyment of learning and close employment avenues (Harlen, 2007). Given these effects, assessment should be fairly and accurately done and hence the relevance of including this aspect in the current study since it is one of the concerns students have in universities. What is of relevance to this study is that the selection of students into CT programme in universities plays a crucial role in determining the quality of graduates produced; the level of knowledge and skills they attain so that they can be absorbed into the world of work.

CT curriculum is supposed to act as a bridge between universities and the world of work. Literature reviewed showed that an inappropriate curriculum has led to the production of graduates whose skills and specialisations do not reflect those needed in the labour market (Quinn et al., 2005; World Bank. (2000). It is argued that the curriculum ought to be culturally relevant to support widening participation and to prepare graduates for living and working in a diverse society (Crosling, Edwards \& Schroder, 2008). Heagney (2008) and Thomas (2002), argue that most IHL in developing countries are finding it difficult to produce students with skills needed by the world of work because of the irrelevant curriculum. Bamber and Tett (2001) recommend that relevant course material should be used in CT programmes in universities. Similarly, Haggis and Pouget (2002) suggest that there is need to strengthen the links between the curriculum and students' own experiences and views of the world. Blackwell et al. (2001) argues that the higher education curriculum should offer students the opportunity to reflect on employment and other experiences to explore the learning and skills development that is involved in these activities. Barrie (2005) similarly argues that the TVE undergraduate curriculum from the first year onwards should assist students to develop 'graduate attributes', which, amongst other things, will assist them in future employment, and life more generally. There is need for learning and teaching to develop personal, social and employability skills (Glover et al., 2002). The same author further argues that the extension of partnerships between $\mathrm{IHL}$ and employers are essential to improve the employability of graduates. The literature reviewed above is of paramount importance since it helps the researcher to focus on critical issues that may provide answers to how the relationship between universities and the world of work may pose challenges in the delivery of the CT curriculum in universities. 


\section{Research Methodology}

\subsection{Research Paradigm}

This study adopted the post- positivist paradigm which combines quantitative and qualitative approaches. Both qualitative and quantitative approaches have their strengths and weaknesses, but when used together, these methods can be complimentary and allow for a more complete analysis of the research situation (Cresswell, 2007).

\subsection{Research Design}

The researchers used the concurrent triangulation design. Concurrent procedures involve collecting both quantitative and qualitative data at the same time during the study (Cresswell, 2003). This design was useful in this study since it used both quantitative and qualitative methods as means to offset the weaknesses inherent within one method with the strength in the other method. This enhanced the researchers' understanding of the relationship between the CT curriculum and the world of work from various angles.

\subsection{Population}

Zimbabwe has a total of twelve universities, 8 of which are public universities and 4 private universities respectively. This study targeted all the 4 public universities that offer CT at degree level. There are 4 Clothing and Textiles industries which are fully operational in Harare, so the researcher targeted 2 industries.

\subsection{Sample and sampling procedure}

The sample comprised 32 lecturers, 2 Head of Departments (HODs), 24 students and 2 Operations managers from the Clothing manufacturing industries. To come up with this sample, purposive sampling was used.

\subsection{Data collection methods}

In this research, questionnaires, interviews, focus group discussions, document analysis, observations were used to collect data.

\subsection{Research Instruments}

Two Heads of Departments from both universities were treated to face-to-face interviews, 16 lecturers and 2 Operations managers from the Clothing manufacturing industries. Semi-structured interviews allowed researchers to solicit data from the respondents as they permitted respondents to express themselves at some length (Sarantakos, 2005).

The study also made use of focus group discussions. Twenty four students made up the 4 focus groups. A focus group interview was based on the assumption that group interaction would be productive in widening the range of responses on the relationship between the Clothing and Textiles curriculum and the world of work (Maree, 2007).

The researchers made use of self-administered the questionnaires since they enabled them to gather data in large amounts from respondents (Cohen, Manion and Morrison, 2007). The questionnaire had both closed and open ended questions. Open ended questions enabled the respondents to give their own sentiments with regards the delivery of Clothing and Textiles in universities.

The researchers also analysed documents from various records in the universities and industries. The researchers were careful enough to evaluate the authenticity and accuracy of the records before using them (Maree, 2007). The use of these documents was considered on the assertion that some of the un-captured detail from universities by other sources could be fully captured.

Observations were also carried out. In this study, for the data collection process, the researchers knew in advance what she wished to observe being guided by the research questions of the study and this served time. The advantage of observation was that the researchers were able to record behaviour as it occurred. 


\title{
2.7 Data Analysis
}

Since this study was premised within the framework of the post-positivist paradigm, both qualitative and quantitative data were collected. Quantitative and qualitative data were interpreted together (triangulation) and were analysed concurrently.

\subsection{Measures to ensure Validity/ Reliability and Trustworthiness}

The researchers tested for validity and reliability of the instruments through pilot studying, before their administration to reduce errors. The researchers ensured that the instruments were designed in such a way that they measured what they were supposed to measure, that is the relationship of the Clothing and Textiles curriculum and the world of work in Zimbabwean universities.

Credibility was achieved by making full use of verbatim accounts when reporting the results and applicability was achieved by careful selection of a diverse sample within the study context. In this study, triangulation of different forms of data was done to check accuracy and consistence of the research findings.

\subsection{Ethical consideration}

In this study, the researcher negotiated with gatekeepers for permission to access participants at research sites. Participation in this study was voluntary. Names of universities, Clothing industries, lecturers, HODs and students remained anonymous for they were given codes.

\section{Results and Discussions}

Head of Departments, Lecturers, and industrial personnel responded to what contributions the industry has made in the designing of the CT curriculum. They explained:

\begin{abstract}
We consult industry on content to include in the curriculum. (HOD-B)
By offering attachment places for students. (UAL)

Yes, at one time one university was planning to introduce a degree in textiles and it gave us questionnaires to fill. We gave them advice on how to go about the programme. The problem is the universities do not follow what we advise them. They consider what is comfortable with them. In as much as we want to assist, lecturers feel they are more learned than us, as a result they don't take seriously whatever we suggest, especially after assessing students on attachment. (IP1)
\end{abstract}

The researchers were quick to notice that in universities there was no evidence of any document from industries showing their contributions to curriculum. It goes to show that there was a flaw in the way this curriculum was being designed. HODs were asked by the researcher as she went through department files if they had anything to show that the industries were participating in curriculum development, but they could not produce a single document. Surprisingly, the researchers established from records industrial personnel had filled that the documents showed the areas of improvement in the delivery of CT in terms of theory and practice and areas where students were not doing well which they wrote on yearly basis after students had finished their attachment. On this scenario, the researchers reasoned that the fact that there were no such documents in universities shows how adamant lecturers were to take up advice from industries. Literature reveals that without a sound relationship between universities and industries, the deleterious effects of producing students without the much needed skills in the manufacturing industries will continue to be felt in African countries, and this also includes Zimbabwe (World Data, 2011).

In line with the same revelations, Quantitative data also revealed that the universities and industries did not work in harmony. From the 16 lecturers who responded to the questionnaire, $7(43.75 \%)$ revealed that the industry had not been cooperative at all, $9(56.25 \%)$ stated that it was not easy for industries to participate in curriculum development in universities. The findings revealed that when universities asked for advice on how to run CT courses, the industries were reluctant to help them. It was also unveiled that people in the industry thought the universities wanted to produce students who would compete with them on the job market. The efforts by universities to include industries in CT curriculum in universities have been fruitless since industries were not forthcoming. Literature reveals that one of the most common criticisms of TVE is that it has curricula that are out-dated both in terms of learning theory and relevance to industry (Gamble, 2004). There has been growing attention to the importance of making curricula more responsive to the needs of industry and more focused on promoting the employability of graduates from universities across all countries. 
It was established that lecturers and HODs were in agreement that industries contribute to designing the curriculum through offering students places for attachment. They also highlighted that they consulted industry on what content to include in the curriculum and industries gave them suggestions on how they should run their courses. Of concern from the findings was that industrial personnel felt lecturers were not taking up their suggestions for they deemed it not worthy. Industrial personnel commented that lecturers felt they were educated enough to take advice from people who work in industries. Year in and year out there was evidence showing universities did not implement what they were asked to as evidenced by students' performance. Different students in different year groups kept on repeating the same mistakes, showing this was not remedied at university level. Document analysis done by the researcher revealed that there were documents in universities to show industries were participating in CT curriculum development in universities. On the other hand, findings from quantitative data revealed that lecturers felt industrial personnel saw university students as threats as a result they were not forthcoming in assisting in curriculum development.

Data were also collected to establish from lecturers, HODs and students on the type of machinery they use in their practical lectures. Some lectures indicated that they had industrial machinery in their departments whilst others indicated that they did not have industrial machinery. Egbo (2005a) avowed that building lecturer capacity means that the universities and governing bodies need to provide the necessary resources; materials and equipment that are required to lecture effectively. The same author reiterated that it is impossible to deliver $21^{\text {st }}$ Century education with $19^{\text {th }}$ century tools. This scenario exists in universities. From document analysis it was worth noting that there were some machines that were in the inventory book but not in use in the factory. Revelations from quantitative data concurred with those from qualitative data. Quantitative data unveiled that some universities had industrial machinery and some did not have. The research findings revealed that not all universities used industrial machines in their laboratories. Both quantitative and qualitative data exposed that in University A, the Juki and Singer sewing machines and over lockers were available. However, these machines were different from the ones in industries, as observed. In industries there were heavy duty machines. In university B there were no industrial machines. Students revealed that there were very old industrial machines in university B work room which lecturers used as teaching aids.

Data were also solicited from respondents on how the shortage of this machinery and other facilities affect the acquisition of technical skills by students. Respondents commented:

\begin{abstract}
Students lack the hands- on skills since they have limited time on the machines. They will fail to use some machinery the universities do not have whist on attachment or when they get employed. (UAL)

It will take them a longer time to be accustomed to the daily routines in the factories bearing in mind that industries are business entities not universities. They are after meeting their daily targets not to spend a lot of time teaching students. (UBL)
\end{abstract}

The above revelations entail that shortages of machinery and other facilities affect the acquisition of technical skills by students. Findings showed that students would not be able to operate machinery in industries because of lack of hands on skills. As a result the students would not be competent enough in the world of work. It is worth noting from the findings that the first quarter of the time students were on attachment was spent on supervisors instructing them on how to operate machinery since students would be lacking the skills. Literature reveals that TVE should empower university students with skills aimed at providing individuals with occupational skills for specific employment in specific jobs which would boost the industrial sector (Hawke, 2000). TVE must prepare young people for life by developing their intellect, aptitudes, and talents and by creating opportunities for them to reach their full potential in skill acquisition. If the universities fail to achieve this, then there is bound to be a mismatch between the expectations of the industry and the calibre of students universities would be produce.

It can be deduced from findings that some students, 3(12.5\%) went for attachment for 4 months, $5(20.8 \%) 6$ months, 2(8.3\%) 8 months, 1(4.17\%) 9 months, 2(8.3\%) 10 months and 12(50\%) went for 12 months. Of concern to note from these findings is that $50 \%$ of the students went on attachment for less than the stipulated time (12 months). This had a bearing on students' acquisition of skills for twelve months for attachment were considered long enough to enable students to acquire relevant hands on skills from the industry. If students are exposed to industries for fewer months than the stipulated months, what it meant was that they would not acquire all the relevant skills; as a result they will be under equipped to face the demands of the world of work. This boils back to the issue of the lack of sound relations between universities and industries as discussed earlier on in the study. From document analysis, it was noticed that in university records it was stipulated that the duration of attachment was supposed to be 12 months, but records from industries and universities reflected that there were a number of students who went on attachment for less than 12 months. Quantitative data revealed that in university $\mathrm{A}, 5(31.25 \%)$ lecturers commented that students went for attachment for 10 months and 3 
(18.75\%) lecturers stated that students went for 12 months. From university B, 13 (81.25\%) lecturers stated students went for 8 months and $3(18.75 \%)$ lecturers commented that students went for 12 months. Of interest to note is that this data did not correlate with the data from the students' focus group, lecturers, Heads of Department and the industrial personnel. Chuang, Goh, Stout and Dellmann- Jenkins (2007) affirm that placement of students in various organisations as trainees is an academic requirement to foster the work experience so the students will attain the necessary skills to supplement the training they get in universities.

Industrial personnel also reflected that students could not operate machinery in the industries. They lacked skills on pattern making, basic processes in garment construction. From the industrial personnel's views, they were concerned with how CT was being delivered in universities since they had noticed that some of the skills students lacked when they came for attachment were basic skills they should have learnt in their first year of study in universities. This made it difficult for students to settle in the various departments they had been placed. Studies show that graduates find the transition from university to placement or attachment difficult and are slow to get started because of lack of basic hands on skills (Ball, 2002). Records from the industries also exposed the same scenario that students lacked basic skills, be it on operating machinery, pattern making or garment construction.

From the focus groups, $12(100 \%)$ from university A indicated that they did not get any support from the industry whilst they were on attachment. From university B, $6(50 \%)$ also indicated that they did not get support from the industry. Whilst $6(50 \%)$ indicated that they got financial support in form of a fixed allowance. Documents analysed from the two industries unveiled that the incentives varied from industry to industry. It was evident from the records that in industry 1 students got transport allowances whereas in industry 2 students did not get any allowance. In both industries, students got support in form of materials and trimmings to use for their projects. Quantitative data unveiled that industries supported students in different ways. Ten lecturers (62.5\%) reflected that students did not get any support, 6 (37.5\%) stated they got financial support.

Findings from both qualitative and quantitative data revealed that not all students got support from industry while on attachment and that for those who got support, it varied from industry to industry. The findings showed that students from university A did not get any support from industry while they were on attachment. It was only those students from university B who got the different types of support.

Industrial personnel (IP) also responded on whether students had the mandate to choose which area to specialise in or not. They responded as follows:

\begin{abstract}
Although universities send a programme for industries to follow, it is not sufficient since they don't consult us before they send students on attachment. As a result we let students go through all sections of production for them to benefit more. (IP1)

There is no specialisation. Each student is given a time schedule and follows what the industry is doing, e.g flow of the garment, Planning-marker room-cutting-preparation-assembling-pressing and dispatch. (IP2)
\end{abstract}

From these revelations, the findings kept on revealing that the relationship between universities and industries is unsound as evidenced by the lack of communication between the two institutions. There were some instances when students requested to spent extra time in a section they encountered challenges. The supervisor in charge with the section would arrange in such a way that the student would not be disadvantaged as well as not jeopardising the day to day running of the factory. It also emerged that students did not choose an area for specialisation but they were made to go through all the stages of production as illustrated below:

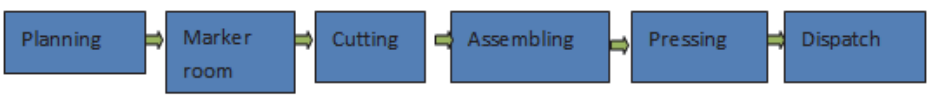

Figure 1: Stages of Production in the Factory

From the findings there seemed to be collaboration between industries for there was some form of uniformity in the manner in which they dealt with students on attachment. Study findings revealed that in both industries under study, the Production manager was responsible for giving students daily tasks. In the factory, there were supervisors who were in charge of monitoring students' daily activities. On the issue of whether industries had enough personnel to monitor students, IP1 and IP2 indicated they had enough personnel since they did not take more students the factories would not be able to accommodate. IP2 commented, "We do not take more than we can accommodate at a time because of capacity problems". 
In reaction to the suggestions Industrial personnel had on the improvement of the quality of students universities are producing, IP1 and IP2 disclosed that:

Time for attachment should be increased so that students leave the industry well equipped with relevant skills and knowledge.

University lecturers should upgrade their knowledge and skills so as to keep abreast with the dynamic fashion, clothing trends and technology so that when students come on attachment, the industrial personnel will just refine the skills not to start from scratch, teaching the students basics they should have done at university level. This will enable them to produce students with the required competence.

Universities should try by all means to buy machinery and equipment that is in line with the changing technologies in industries so that they don't lag behind in terms of skills acquisition.

It would be wise for universities to consult the industry before they design their CT curriculum so that the industry has an input.

Of interest to note is that the industrial personnel distinguished the need for staff development on the part of lecturers so that they kept abreast with the dynamic world of clothing and textiles. They also emphasised on the need for universities to buy machinery and equipment which is commensurate with the ones industries are using. Findings reveal that universities and industries should work in unison so as to come up with a curriculum that is in harmony with what happens in the two environments so as to enhance acquisition of skills by students. It was also revealed that the time for attachment was too short for meaningful mastery of skills by the student.

\section{Conclusions}

The delivery of CT in universities was further strained by the lack of cooperation between universities and industries. Most of the challenges students and lecturers encounter stem from the fact that universities do no consult industries when they are designing their CT curriculum. The lack of a clear link between universities and industries is a major contributory factor to the type of students universities are producing; students who lack the qualities needed by the world of work. This has study has put more value and emphasis to these momentous issues that may pose serious challenges to the delivery of the CT curriculum within the institutional context and need to be borne in mind and consistently addressed.

\section{Recommendations}

The study recommends that universities should consult industries in curriculum designing since this will curb the challenge of students not possessing the adequate hands on skills which has remained a far cry.

Time for attachment should be lengthened so that students leave the industry well equipped with relevant skills and knowledge.

There is need for the universities in liaison with industries to come up with policies that focus on student attachment as to lessen the likelihood that students are left susceptible and at risk of being unattached to any industry when they are left to look for attachment places by themselves.

\section{References}

Baba, Y., Shichijo, N., \& Sedita, S. R. (2009). How do collaborations with universities affect firms' innovative performance? The role of "Pasteur scientists" in the advanced materials field. Research Policy, 38(5), 756-764.

Ball, L. and Price, E. (1999), 'Rethinking Business Start Up - a new model for success in art and design', Research Report, Project Findings: Graduate into Business, A Research Project funded by the DfEE Higher Education Regional Development Fund 19982000, University of Brighton, School of Architecture and Design.

Ball, L. (2002). Preparing graduates in art and design to meet the challenges of working in the creative industries: a new model for work. Art, Design \& Communication in Higher Education, 1(1).

Bamber, J \& Tett, L 2001, 'Ensuring integrative learning experiences for non-traditional students in Higher education', Journal of Widening Participation and Lifelong Learning, 3.1, p8-18.

Barrie, S (2005), 'Starting the journey towards generic graduate attributes for a super-complex world', paper presented to the European Association for Research on Learning and Instruction 11th Biennial Conference, University of Cyprus,Nicosia, Cyprus, 23-27 August 2005.

Bekkers, R., \& Bodas Freitas, I. M. (2008). Analysing knowledge transfer channels between universities and industry: To what degree do sectors also matter?. Research policy, 37(10), 1837-1853. 
Blackwell, A, Bowes, L, Harvey, L, Hesketh, AJ \& Knight, PT 2001, 'Transforming work experience in higher education', British Educational Research Journal,27.3, pp. 269-285.

Burroughs, S. (ed.) (2000), From Learning to Earning - Connecting Art, Craft and Design in Higher Education with the Creative Industries, A Review of Regional Issues, Arts Council of England.

Castells, M., (2006). The network society: From knowledge to policy (pp. 3-23). Center for Transatlantic Relations, Paul H. Nitze School of Advanced International Studies, Johns Hopkins University.

Chuang, N. K., Goh, B. K., Stout, B. L., \& Dellmann-Jenkins, M. (2007). Hospitality undergraduate students' career choices and factors influencing commitment to the profession. Journal of Hospitality \& Tourism Education, 19(4), 28-37.

Cohen, L., Manion, L \& Morrison, K. (2000).Research Methods in Education. New York: Routledge Falmer.

Cohen, L,. Manion, L., and Morrison, K., (2007). Research methods in education. Padstow: Cornwal.

Creswell, J. W. (2003). Research design; Quantitative, and mixed methods approaches. London: Sage.

Creswell, J. W. (2007). Research design: Qualitative, Quantitative and Mixed methods approach (2nd Ed). Thousand Oaks: Sage Publication.

Crosling, G, As-Saber, S \& Rahman, N (2008), 'Postgraduate International Students and Independent Learning'. Paper presented at International Conference on Postgraduate Education, 16-17 December, 2008, Penang, Malaysia.

Crosling, G., Heagney, M., \& Thomas, L. (2009). Improving student retention in higher education: Improving Teaching and Learning Australian Universities' Review, 51(2).

Daily Sun, 2011

DTI ( 2009) Smarter, Faster, Better e-Government 8th Benchmark Measurement.

Egbo, B. (2005a). Transformative Learning in a Changing World: Guidelines and Strategies for Practice. Sixth International Conference on Transformative Learning. Michigan State University, East Lansing, Michigan. Oct 6-8, 2005.

Gamble, J. (2004). A future curriculum mandate for Further Education and Training colleges: recognising intermediate knowledge and skill. Shifting Understandings of Skills in South Africa. Overcoming the Historical Imprint of a Low Skills Regime, 175-193.

Glover, D, Law, S \& Youngman, A 2002, 'Graduateness and Employability: student perceptions of the personal outcomes of university education', Researching Post-compulsory Education, 7(3).

Haggis, T \& Pouget, M (2002), 'Trying to be Motivated: perspectives on learning from younger students accessing higher education', Teaching in Higher Education,7 (3) pp. 323-336.

Harasim, L. (2000). Shift happens: Online education as a new paradigm in learning. The Internet and higher education, 3(1), 41-61.

Harlen, W. (2005). Teachers' summative practices and assessment for learning-tensions and synergies. The Curriculum Journal, 16(2), 207-223

Hawke, G. (2000) Implications for Vocational Education of changing work arrangements. Paper presented to the Professional Development Series, National Dissemination centre for Career and Technical Education. Ohio State University: Columbus, Ohio.

Heagney, M. (2008). Student success and student diversity. Improving student retention in higher education: The role of teaching and learning, 17-28.

Hutton, E. (2009). An examination of post-positivism and post-modernism. Hutton Behavior Analysis.

Kariwo, M. T. (2007). Widening access in higher education in Zimbabwe. Higher Education Policy, 20(1), 45-59.

King, K. (2011). Towards a new global world of skills development? TVET's turn to make its mark. NORRAG News, 46.

Makochekanwa, A., \& Kwaramba, M. (2010). Dwindling access to basic services in Zimbab

Maree,K, (2007) First Steps In Research. Van Schaik Publishers, Pretoria, South Africa.

Maree, J. G. \& Frazer, W.J. (2008). Outcomes based Assessment: Facilitating best practice in classrooms. Johannesburg: Heinemann Publishers Pvt. Ltd.

Morgol, G. (2001). What is complexity science? Postmodernist or postpositivist?. Emergence, 3(1), 104-19.

Purcell, K and Quinn, J (2005), "Hospitality Management Education and Employment Trajectories, School of Hotel and Catering Management", Oxford.

Quinn, J, Thomas, L, Slack, K, Casey, L, Thexton, W \& Noble, J (2005), From LifeDisaster to Lifelong Learning: Reframing Working Class 'Drop Out'. York:Joseph Rowntree Foundation.

Royal College of Art (1998), Destinations of Royal College of Art Leavers 1992-1996,

London: unpublished report.

Rowley, J. (2012). Conducting research interviews. Management Research Review, 35(3/4), 260-271.

Ryan, A. B. (2006). Post-positivist Approaches to research. In researching and writing your thesis: A guide to postgraduate studies. MACE: Maynooth Adult and Community Education, (pp. 12-26).

Sakamota, A \& Powers, P.A (1995) Education and dual labour market for Japanese men in American Sociol. Rev., 60 (2): $222-246$.

The Sunday Mail 11 August 2012)

The Zimbabwean Herald June, 29 2012).

Thomas, E, Woodrow, M \& Yorke, M. 2002, 'Access and Retention', in Layer, G etal. (eds) Student Success in Higher Education. Bradford: Action on Access.

Turnbull, M., Littlejohn, A., \& Allan, M. (2012). Preparing graduates for work in the creative industries: a collaborative learning approach for design students. Industry and Higher Education, 26(4), 291-300

UNESCO (2003) Global monitoring report: gender and education for all. The leap to equality (Paris, UNESCO).

UNESCO. 2010. EFA global monitoring report 2010: Reaching the marginalised. Paris: UNESCO. 
Van de Werfhorst, H. G. (2007). Vocational education and active citizenship behavior in cross-national perspective. Amsterdam: University of Amsterdam.

World Bank (2000). In Small states: Meeting challenges in the global economy.

World Bank, (2002). Globalisation, Growth and Poverty. Washington, D.C.

World Data on Education- Zimbabwe, $7^{\text {th }}$ Ed, and November, 2011.

Yorke, M \& Longden, B 2004, Retention and Student Success in Higher Education,Maidenhead, UK: Open University Press. 